Јелена Ђ. Гојић

Универзитет у Крагујевцу

Филолошко-уметнички факултет

Катедра за германистику
УДК 821.112.2-31.09 Ман Т. https://doi.org/10.18485/uzdanica.2020.17.1.5

Оригинални научни рад

Примљен: 28. фебруар 2020.

Прихваћен: 1. јун 2020.

\title{
МОТИВИ ГОРДОСТИ И ПРАШТАҢА У МАНОВОМ РОМАНУ ЈОСИФ И ЊЕГОВА БРАЋА СА ОСВРТОМ НА БИБЛИЈСКО-АПОКРИФНЕ СПИСЕ
}

$A \bar{u} c \bar{u} p a \kappa \bar{u}:$ У раду се истражује развој мотива гордости и праштања у лику Прекрасног Јосифа на основу текстуалних предложака који имају упориште у библијско-апокрифним списима и другом делу тетралогије Томаса Мана Млаgи Јосиф. Старозаветна

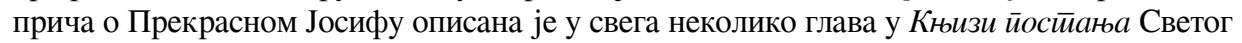
писма, али, поред ње, списи који сведоче о напаћеном Јосифу и његовом успону на животном путу налазе се у неколико верзија апокрифа у којима се из више перспектива сагледава Јосифов живот. Томас Ман се враћа на причу о Јосифу и обликује је на свој начин, при чему преиначава овај библијски лик у једну посве комплексну личност. Компаративном анализом долази се до закључка да Томас Ман гордост и праштање поставља као централне елементе у развоју Јосифове личности, при чему се гордост у лику Јосифа не појављује у библијско-апокрифним списима. Мотив опроста присутан је пак у свим текстовима. Међутим, у библијско-апокрифним списима, мотив опроста појачава врлине Прекрасног Јосифа, док код Томаса Мана има кључну улогу у приказивању његовог преображаја.

Кључне речи: Томас Ман, Јосиф и њеїова браћа, Млаgи Јосиф, апокрифи, прекрасни Јосиф, гордост, опраштање.

Старозаветни и новозаветни текстови су у свим књижевним епохама били у функцији прототекстова из којих настају сасвим нови дискурси као интерпретације и реинтерпретације примарног (или изворног). Међутим, текст који се заснивао на библијској тематици, а није постао део Светог писма, дефинисан је као апокрифни и није се нужно значајно разликовао од канонског дискурса. У апокрифним текстовима, у зависности од врсте, постоје мања или већа одступања од библијског текста, али су у њима садржане личности, теме и мотиви које налазимо и у Библији. Оно што их разликује од текстова који су одговарали нормативу Светог писма јесте стил у приказивању прича, динамично и сликовито приповедање, али у одређеним случајевима и изме-

jelena.gojic.kg@gmail.com 
не у садржају. Како се у њима могло наћи детаљнијих описа у виду допуне садржаја о одређеним библијским личностима, што је, подразумева се, било одступање од библијског канона, апокрифни списи су били забрањени. Као такви, били су окарактерисани као тајни списи (уп. Јовановић 2005: 9-10).

Интересовање за библијско-апокрифне списе присутно је и у 20. веку, што доказује роман Томаса Мана Јосифб и њеїова браћа, на ком је Ман радио пуних шеснаест година и због којег је подробно истраживао различите списе и чак спровео путовања до Египта и Палестине. Овакво истраживање изнедрило је тетралогију, при чему су књиге хронолошки постављене тако да прва, Јаковљеви gоживљаји, одговара опису Јаковљевог животног пута, опису љубави према Рахили и потешкоћама на путу остварења љубави са својом Правом. Затим, Млаgи Јосиф, почетак приче о Јосифу, док трећа и

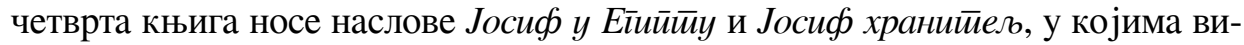
димо наставак Јосифовог самосталног живота далеко од своје породице. Сва четири дела заправо имају за задатак да покажу живот младог Јосифа који је у својој појави био изразито посебан и који је то и сам знао да препозна, али и да се кроз приказивање његовог живота укаже на одређене митске обрасце који се кроз различита времена понављају. Наклоњеност митологији Ман објашњава тако што човека у одређеним годинама напушта интересовање за оно што је индивидуално и посебно, те преовладава жеља за изучавањем оног типичног, што је у основи увек митско (Глушчевић 1970: 40). У коришћењу митолошке грађе као основе за стварање Ман није усамљен, већ је то, како Мелетински (1983: 301) наводи, карактеристична појава у 20. веку, не само у виду уметничког стварања, већ и у осликавању односа према свету.

Основни сиже Јосифа и њеїове браће преузет је из старозаветне приче, с тим што је Ман продубљује и детаљније проблематизује одређена поља која нису расветљена ни у библијској причи, а ни у апокрифним списима. О људским жељама, могућностима, немогућностима и побудама Ман нашироко приповеда, уз честе коментаре који воде ка бољем разумевању приче (Стојановић 1997: 115). Стога у раду полазимо од осврта на старозаветну причу, чије разумевање употпуњујемо различитим верзијама апокрифа о Прекрасном Јосифу, како бисмо компаративном анализом потом истражили извесне аналогије у лику Јосифа код Томаса Мана. Сходно томе, у средиште наше анализе постављамо други део ове тетралогије који носи назив Mлagu Jocug, јер се управо у том делу налази окосница читаве радње романа - опис Јосифовог односа према браћи, оцу и околини, његова учења, као и тренутак ескалирања мржње старије браће према Јосифу. Оваквим приступом желимо да укажемо на циклични развој митске ситуације у линеарном времену, са освртом на фигуру Јосифа који доживљава свој развој од горде, набусите личности, до онога који је умерен, мудар и склон праштању. Управо то и постављамо као предмет рада. 


\section{АПОКРИФНИ И БИБЛИЈСКИ ПРЕКРАСНИ ЈОСИФ}

Старозаветна прича о прекрасном Јосифу, праобразу Исуса Христа, већ хиљадама година пружа инспирацију и надахњује ауторе из различитх области стваралаштва - од књижевности до цртаног филма (Анђелковић, Пајић 2011: 265). Тематски сиже приче усмерен је ка Јосифу, његовом развојном путу, као и великој љубави према оцу, сукобима са браћом и истрајној верности према Богу. Као таква, због свог дидактичког садржаја и у њој садржаних мотива, ова прича вековима представља неицрпан извор утехе за недужне и невине који трагају за спасењем и надом.

Биолијска прича о Прекрасном Јосифу испричана је у Књизи постања са почетком у 37. глави и завршетком у 50. глави, при чему у 38. глави долази до малог екскурса, па се у њој приповеда о Јудином животу. Поред тога, сведочења о прекрасном Јосифу налазимо и у апокрифима. Уз мање-више запажене дистинкције, оно што се уочава као главни костур ових апокрифа јесу три главне приче: „продаја Јосифа и одвођење у ропство; лажна оптужба Петефријеве жене и одвођење у тамницу; постављање Јосифа за владара и клањање браће" (Анђелковић, Пајић 2011: 267). На то се може додати и мотив опроста браћи, што у целости заокружује причу о личности Јосифа, који никада није чинио против Божије воље и који је због тога напослетку био награђен. Један од занимљивих детаља, додуше и усамљених јер се тако нешто не појављује ни у једном другом спису где има помена Јосифа, налази се у апокрифу О йрекрасном Јосифу и како їа йроgаgоше браћа (йрва верзија). При самом крају, у тексту се говори о Венјаминовој мржњи према синовцу који је био одабран да буде благословен, док се са том мржњом рађа и мржња према брату Јосифу. Венјамин изнова покушава да убије Јосифа и Јефрема, док се Јуда, који је покретач злодела које су браћа учинила над Јосифом продавши га у робље, брине и буни због Венјамина, тражећи начин да га заустави у својој намери (уп. Јовановић 2005: 283-295). Јосиф је несумњиво жртва мржње своје браће, али, како је његова животна прича показала, због злодела која су му учињена и његовим одговорима на њих, успео је да се издигне у Божијим очима јер је остао веран и истрајан у служењу Богу, чинећи увек исправне ствари.

Постоји и друга група апокрифа која нас дубље и детаљније уводи у Јосифов поглед на љубав, искушења у разним ситуацијама са женама ${ }^{1}$ и ње-

${ }^{1}$ Неизоставни елемент сваке приче о Прекрасном Јосифу јесте ситуација у коју доспева због похотности једне жене која жели да куша његову љубав, а на тај начин и његову верност Богу. Та жена је била удата, штавише, била је жена Петрадина (О йрекрасном Јосифу како $\bar{a} a$ йpogagome браћа (gруі̄a верзија)), тј. Пентефрија (О Прекрасном Јосифу како йа йроgаgоше

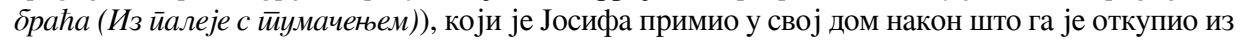
ропства и допустио да има све на располагању, осим његове жене (Јовановић 2005: 298). Како Јосиф одбије блискост са женом, она прибегава подвали и Петрадин баца Јосифа у тамницу. 
гов брак са Асенетом. У овом апокрифу добијамо увид у преображај једне јаке, доминатне женске фигуре која при првом погледу на Јосифа одлучује да одбаци своју веру и принципе. Након што уследи процес Асенетиног религијског и потпуног личног преображаја који је врло сликовито и детаљно описан у апокрифу Жийије и исйовесй Асенейе (Јовановић 2005: 320-340), Јосиф је узима за жену и са њом добија двоје деце, синове Манасију и Јефрема. У старозаветној причи у Библији Посйање, глава 48 (Свето писмо 1992: 42-43), епизода са Асенетом није ни најмање развијена. Она се помиње само као његова жена која му рађа двојицу синова, али је од великог значаја део где Јаков на самрти свој благослов не даје Јосифовом првенцу Манасији, већ млађем Јефрему, што у Јосифу изазива љутњу. Међутим, на овај начин Јаков остаје доследан својим праоцима, као и схеми на којој је заснована прича о Аврамовим потомцима, јер ниједан првородни у породичној лози није добио благослов.

Иако апокрифи списи не спадају у библијски канон, када говоримо о причи о Прекрасном Јосифу и његовој личности, у њима нема никаквих одступања од онога како је Јосиф приказан у старозаветном предању. Апокрифи нам, пак, сликовитим и динамичним начином приповедања пружају потпунију слику о Јосифовом путу уздизања, при чему на том путу остаје веран својим врлинама и не чини никакво зло нити преступе. Тако приказан, он представља слику идеалног човека који у теоријском систему о религијском учењу - теологији, пружа адекватан узор свим нараштајима и генерацијама².

\section{МИТОЛОГИЈСКО-ТИПСКИ ОБРАЗАЦ У ТЕТРАЛОГИЈИ TOMACA MAHA}

Томас Ман је за рад на овој тетралогији спровео исцрпна истраживања, те стога 1925. године путује у Египат, а затим 1930. у Палестину (Педерин 2008: 509). Како је Ман био протестант, користио се Лутеровим преводом Библије, али је поред Свете књиге изучавао и куранске списе, египатску и феничанску митологију로 , а била је довољна и једна реченица из Гетеове По-

Јосиф ће управо у тој тамници срести двојицу затвореника и тумачећи им снове избавити себе. Оставши веран Божији слуга, Јосиф бива награђен и фараон га поставља да царује у Египту.

${ }^{2} \mathrm{O}$ томе да је прича о Јосифу поучна за све нараштаје говори и чињеница да су на основу управо те приче снимљени филмови, што за одрасле, то и за децу, али и да се управо тај дидактички потенцијал који прича носи у себи користи у образовању и васпитању деце. Стога постоји и дидактички потпуно осмишљен и описан предложак за рад у настави са ученицима основне школе од првог до четвртог разреда у Немачкој. Предложак чини це-де са филмом који траје једанаест минута, слике које прате радњу (20 слика), девет радних задатака, као и образложење васпитних и образовних циљева (Институт за филм и слику 2012).

${ }^{3}$ Педерин (2008: 509-510) даје исцрпан преглед тачних списа који су Ману послужили у изради романа у оквиру тетралогије Јосиф и њетова браћа. 
езије и истиине да га подстакне да се позабави овом темом (Глушчевић 1970: 39). Тематско упориште Мановог романа чини у основи легенда о Јосифу, при чему се Ман ослања на научну традицију и у осетној мери се препознаје Јунг и његово учење о архетиповима. Ман пише митолошки роман, али то није роман у коме треба препознати и ишчитати митске обрасце, већ акценат јесте на митологијском сижеу, при чему митолошке приче шири, обнавља их и указује на њихово понављање кроз типичне митске обрасце. Као што Мелетински (1983: 338) наводи, „тај сиже је, додуше, узет из једног извора и представља [...] 'историзован' мит или митологизовано историјско предање”.

У Јосифу и њеїовој браћи Ман укида време као трајање (Кордић 1975: 16) и не пише историјски роман, већ кроз приказивање понављања митских схема указује на ванвременост митова тако што осветљава унутрашњу повезаност митова са типским. Отварајући поглавља о познатој и сажето испричаној причи о Јосифу у Библији, Ман нашироко не приповеда само о животу појединца и његовом индивидуалном животном путу, већ открива општа и схематска поља која прате сваког појединца и друштва уопште. Кроз типичну митску фигуру приказане су карактеристике које су поновљиве и које се понављају у понашању различитих индивидуа, без обзира на време и простор у коме живе (Тартаља 1986: 65). Кроз животне путеве Јосифових праотаца које Ман приказује у својим романима - Аврамов пут и његово тражење Бога, помињање Исака, а затим и детаљно испричан пут Јакова, указује се на одређене обрасце који су и типски и поновљиви, као и на то да ниједан појединац није усамљен на свом путу развоја и сазнања јер упориште свог пута може пронаћи у вечним понављањима која прате људске судбине, независно од историјског времена. Како појединце понаособ прате различити митски, тј. типски обрасци, појединац их не преузима свесно, већ се у њему они обнављају и у различитим историјским временима понављају несвесно (Тартаља 1986: 67). Кроз Јосифа и њеїову браћу Ман успева да индивидуално време и судбину пренесе на ступањ општости и уз то прикаже вечност трајања митско-типских образаца. Служећи се тим обрасцима, Ман приказује да смрт појединца није крај (Хајмендал 1998: 300), већ означава живот и вечност - „Умрети, то, наравно, значи изгубити време и отићи из њега, али то уједно значи стећи вечност и трајну садашњост, а то значи прави живот" (Ман 1990а: 53).

Најбољи пример за доследност понављања митских образаца је Елијезер. Он је Јосифов учитељ и Јаковљев најстарији слуга који Јосифа упознаје са причама о прецима, говорећи притом у првом лицу када помиње Елијезера који је путовао у Месопотамију као просац Ребеке у Исаково име. Он то, разуме се, никако није могао да буде јер би то значило да је стар неколико стотина година. Упркос томе, он остаје веран причању у првом лицу јер се идентификује са искуствима свих Елијезера пре њега. Он не представља појединца у модерном смислу, већ слику „митске институције” (mytische 
Institution) (Хајмендал 1998: 303) и тако очито потврђује понављање митских образаца. Елијезер, пак, није усамљен у изједначавању са митским пратиповима. Наиме, Јакова прате сличне приче као Исака и Аврама. Како Хајмендал (1998: 303) наводи, понављање митских образаца овде само утврђује њихову позицију у друштву и чини културалну основу за разумевање постанка израелског народа.

\section{НАРЦИСОИДНИ ЈОСИФ}

У Јосифу и њетоовој браћи Ман се одваја од својих устаљених грађанских тема и ликова који су до тада заузимали централно место његовог интересовања и углавном се одликовали неким телесним или нервним потешкоћама, те се стога чини као да нису могли да превазиђу антагонизам духа и душе да би живели у складу. Лик Јосифа гради на потпуно другачији начин. Ослањајући се на Свето писмо, Ман преиначава један библијски лик не би ли показао да је могуће доћи до хармоније и споја духа и душе.

Лик Јосифа се у библијско-апокрифним причама одликује највећим врлинама које се у карактеру једног човека могу замислити. Отелотворење његове личности пропраћено је добрим и умереним особинама, при чему није био склон претеривању у истицању своје посебности, која се између осталог састојала у дару да тумачи снове, кроз које је могао да прорекне будућност. У библијско-апокрифним причама, браћа нису наклоњена Јосифу, а један од разлога за то је Јосифов дар тумачења снова. У једном од својих снова, Јосифу се потврђује да ће господарити и да ће му браћа служити. То је био главни окидач да се мржња у старијој браћи распламса, те одлуче најпре да Јосифа убију, а затим да га баце у јаму. Касније се ипак предомисле и продају га Египћанима у робље. Оно што разликује библијску причу од апокрифа јесте управо Јосифов глас, пре свега када га браћа бацају у јаму. У библиској причи Јосиф не проговора, са његовим речима се сусрећемо тек касније, те не можемо знати каква је његова реакција на дело његове браће. У апокрифима, пак, добијамо увид у то колико је Јосифу било тешко због чина његове браће и колико је патио што ће бити далеко од очеве куће и мајчиног гроба.

Кроз свако Јосифово делање у библијско-апокрифним причама потврђује се његова доброта и врлина. Чак и у разговорима са својом браћом, он не ликује над судбином која ће их неминовно задесити, јер ће се Јосифово привиђење засигурно обистинити, већ им само приповеда о свом сну. У апокрифним причама, Јосиф извештава своју браћу о свом сну, али прича није довољно развијена да бисмо знали да ли то ради из разлога да би ликовао и постављао себе изнад своје браће или им само пружа информације о свом 
сну. Међутим, делови прича пре и после показују да су у Јосифу доиста владале врлине целим његовим бићем.

Ман, пак, шири легенду о Јосифу, те имамо прилику да из различитих углова и са различитих аспеката сагледамо Јосифову личност, која нашироко отвара она поља која су укратко постављена у старозаветној причи. Јосифа одликује мудрост, лепота, богатство многим знањима, али, поред тога, његова личност се у Мановој тетралогији разликује од архаичних текстова у којима се Јосиф одликује само врлинама. У Мановом Јосифу преовладава читав спектар особина. Како ће епизоде са Венјамином показати, поред доброте, љубави и мудрости, у њему се могу појавити љубомора спојена са страхом да не буде надмашен у својим знањима, као и лукавство, потказивање браће, за које и сам признаје једном да је било претерано (Ман 1990б: 62). Кроз поступке које Јосиф чини стиче се утисак да се служи оваквим особинама не би ли остао најбољи. Јосиф не жели да дозволи да било ко други заузме место које он има у друштву и, најпре, у очима свога оца Јакова. И сам Јаков га у једном наврату моли да му се не додворава како би добио оно што је наумио (Ман 1990б: 102). Јосиф се, дакле, служио и средствима која нису била увек оправдана. У једном од разговора са оцем, Јосиф га на врло лукав начин моли да му саопшти шта је то што је обећао да ће му једног дана припасти. Јаков одбија, али га Јосиф вештим реторичким способностима наговара, приказујући извесне особине које алудирају на присуство нарцисоидности, оваплоћене у његовом лику.

„Зар да не видим оно што је моје и мени обећано? Дакле, урадимо онда овако: Ја ћу се сав скупити, ево ту на овом месту, као да сам везан, и нећу се помаћи с места. А ти ћеш донети и показаћеш ми свечану хаљину, узећеш је и држаћеш је пред собом онако као што трговац у Хеврону у радњи муштерији показује робу и шири и преврће тканину пред његовим пожудним очима. Али овај је сиромах и не може да је купи. Тако трговцу на крају не преостаје ништа друго него да своју робу склони.” (Ман 1990б: 105)

Јосиф је потпуно убеђен да ће Јаков њему дати благослов и ка њему усмерити наследни избор, иако то Јаков ни у једном моменту не потврђује.

„Нека буде у име Господа”, рече Јаков, „Неком ко би све ово посматрао са стране зацело би се учинило да можеш да чиниш са мном шта ти је воља. Остани ту где си! Седи на ту једну ногу, а руке држи за леђима! Нека ти буде, видећеш оно што ће једном можда бити твоје, ако то околности буду допустиле.”

„Оно што је већ моје!” викну Јосиф за њим. „И што само још немам, што још није у мојим рукама!” (Ман 1990б: 105)

И поред Јаковљеве жеље да остане при својој одлуци, он попушта пред Јосифовим убеђивањем и износи му Рахилин вео у ком Јосиф изгледа као право оличење божанства. И до тада је Јосиф показивао особине које се не 
подударају са оним из библијско-апокрифних прича, а то су пре свега гордост и надобудност. Свестан својих психо-физичких квалитета, каналише их у погрешном смеру. Егоизам и самољубље које се претварало у нарцисоидност и уверење да га свако мора волети највише, више од самих себе (Стојановић 1997: 123), довели су до тога да га браћа замрзе до те мере да пожеле његову смрт. И пре него што је добио вео, Јосиф је поступао гордо служећи се сазнањем о љубави коју отац осећа према њему. Чињеницу да Јаков у њему види Рахилу Јосиф користи да се издигне изнад свих, па и изнад старије браће. Егоцентричност присутна у лику Јосифа појачава се након добијања вела јер, свестан своје лепоте, ликује над својом појавом. Врхунац Јосифове нарцисоидности представља тренутак када одлучи да се у мајчином велу појави пред својом браћом на ливади ${ }^{4}$ У браћи се бес само појачавао и кулминирао је управо због овог комада одеће. Јосифова појава изазвала је такав револт у браћи да му чак нису дозволили ни да каже више од пар речи, одмах су га напали и умало на смрт претукли, о чему ће бити више речи у наставку рада.

Место које упућује на проблематику Јосифовог самољубља као везу са проблематиком идентитета повезује се са сновима који се код њега јављају као привиђење будућности (Клерико 2004: 101). Сусрет са другима користи за величање себе, чега у библијско-апокрифним причама нема. Самопоуздање, самовоља и гордост појачавају се услед снова које сања, о којима не говори свима, већ само свом поверенику, млађем брату Венјамину. Свестан је последица до којих би дошло када би испричао све сне, али опет одлучује да браћи саопшти један од снова, а тиме и да им укаже на будућност. У том сну, кроз алегорију снопова жита који једино у Јосифовом пољу стоје усправно, Јосиф их наводи да сами протумаче сан уз речи: „Наиме, онај ко је уснио сан, не треба и да га тумачи, већ то треба неко други да учини" (Ман 1990б: 135). Браћа су знала да тај сан значи да је Јосиф одабран да влада. Сан се може протумачити као парафраза постанка његовог Ја, као потврда њега као индивидуе насупрот колективу, тј. осталима (Клерико 2004: 101), што се одражава и у његовом односу према браћи.

\section{ЈОСИФОВА ГОРДОСТ ПРЕМА БРАЋИ}

Од Јосифовог рођења је било јасно да ће остала браћа, иако старија, бити остављена по страни и да ће их отац занемарити јер је Јосиф плод велике велике љубави између Јакова и Рахиле. Јосиф, дакле, самим рођењем

${ }^{4}$ Јосифова браћа се налазе на ливадама далеко од куће, где обављају своју пастирску дужност након што су саопштили Јакову да одлазе од њега. Разлог најављеног одласка од оца је тај што је Јаков предао Јосифу вео. Јаков шаље Јосифа да их врати кући и, иако Јосиф заиста воли своју браћу и, иако свестан шта би појава у велу могла да изазове код браће, одлучује да се испред браће појави у велу уз смех и лепо расположење. 
бива предодређен и изабран за наследника, али како је одрастао све више се издвајао из масе, а нарочито од своје браће, и то пре свега по лепоти, а затим и по мудрости. Јосиф је био толико леп да се о његовој лепоти причало нашироко и надалеко. Нико не би могао да не примети његову појаву и лепоту, без обзира на мишљење о његовој личности. Равнодушност према његовој лепоти није била могућа, због чега га Ман наизглед издједначава са божанским бићем.

[...] без обзира на то да ли смо ми у стању или нисмо да се прикључимо том усхићењу - да је његова љупкост веома рано, и то у позамашном делу земље, постала пословична. А уз то је била опремљена способношћу да у себе укључи и духовно и све његове уметности, да га захвати с ведром ревношћу, да га упије у себе и да га опет, обележена њиме, печатом љупкости, зрачи из себе, тако да између обојега, између лепоте и духа, више није постојала никаква супротност, нити је међу њима било више икакве разлике. Рекли смо да је уклањање њихове природне напетости морало да остави утисак божанског. (Ман 1990б: 27)

У даљем тексту Ман истиче да је, иако са особинама приписиваним божанском бићу, Јосиф ипак људско биће које није непогрешиво. Његов однос према брату Венјамину, брату и по оцу и по мајци, био је умногоме другачији него према полубраћи. Јаковљеви синови су, може се приметити, били подељени у две групације, где су са једне стране били старији Јаковљеви синови којих је било десеторица и млађи синови, Јосиф и Венјамин, чија је мајка била Рахила. Како је Рахила била велика Јаковљева љубав, Јосиф и Венјамин су стога по рођењу имали већу наклоност свога оца. Рахилини синови су доста времена проводили заједно, нарочито од доба када је Венјамин порастао и није било неопходно пружати му стално старање. Од своје осме године проводи више времена са старијим братом Јосифом, према коме је осећао велику приврженост и наклоност, а Јосиф је осећао да је њихова повезаност посебна и, напослетку, „природна” (Ман 1990б: 61), те је у Венјамину видео правог пријатеља и повереника. Разлика у годинама је била приметна, али ју је Јосиф занемаривао, па је са Венјамином разговарао као са својим вршњаком. Уистину, Венјамин није могао увек да схвати све оно о чему Јосиф прича, али је истовремено био срећан и поносан због односа какав су имали.

Венјамин често истиче како је он незрео и тек „шврћа”, показујући у исто време и изразиту зрелост, јер свестан своје незрелости и година отвара могућности за нова сазнања и учења. И не само то - наглашавајући своју незрелост, Венјамин повремено истиче своју мајушност - интелектуалну и физичку - насупрот Јосифу кога велича јер сматра да је најмудрији и најлепши. Венјамин поступа тако као да би било погрешно да са тако мало година један дечак покаже равноправну мудрост насупрот Јосифовој. На тај начин, стиче се утисак да је Венјамин неретко вешт у истицању мудрости свога брата, што свакако подстиче Јосифово самопоуздање. Међутим, Венјамин је по својој природи врло бистар и показује да има изразито оштар ум и истанчан њух 
за ситнице и детаље. Врло добро уочава појединости, што некада и разљути Јосифа јер су то обично биле појединости о којима Јосиф није имао сазнања.

„У какво дрво?” [пита Венјамин]

„Било је то дрво или грм”, рече Јосиф љутито, „или грм јак као дрво. Нисам био у близини да бих ти могао рећи какав је нос био у краља и какве је минђуше имала дадиља краљеве ћерке. Ако ти је до слушања, онда слушај а немој ми постављати незрела питања као да би да бацаш клипове у точкове!”

„Ако ћеш да ме грдиш, онда ћу се заплакати”, потужи се Венјамин, „па ћеш онда морати да ме тешиш. Зато немој одмах да ме грдиш и веруј ми да не желим ништа друго него само да те слушам!" (Ман 1990б: 76)

Јосиф не уме да прикрије љутњу коју у њему изазвају Венјаминова питања, која управо задиру у појединости и врло су честа. При образложењу одговора, Јосиф поново упућује прекор млађем брату у нешто блажем тону, али са видљивим негодовањем, говорећи му: „Ти баш мораш све да питаш и све да знаш" (Ман 1990б: 76). Иако је однос између двојице браће друкчији него са онима који нису синови њихове мајке, и овде примећујемо извесна колебљива струјања између Јосифа и Венјамина. Наиме, када се Венјамин родио, Рахила је умрла на порођају. Због тога Венјамина зову, а то и он сам чини, „синчићем смрти”, док се у Јосифу огледа сва Рахилина лепота. Сам Јосиф говори да у њему живи мајка, да су они једно биће и да управо у томе лежи разлог толиког обожавања које према њему усмерава Јаков. Он у Јосифу види Рахилу. И не само он, и Венјамин потврђује ту Јосифову тврдњу, откривајући да му он замењује присуство мајке. Но, разлика између мајке и Јосифа постоји и то сам Венјамин каже, јер мајчина је љубав безусловна и несебична, а Јосиф одређена знања задржава за себе и не дели све са својим братом. Чак ни са њим, иако га сматра својим повереником и пријатељем. Несумњиво је да Јосиф жели да његов млађи брат сазри и овлада знањима, али како је он тај који Венјамину преноси знања, Јосиф је у позицији да одлучује која знања и када Венјамин треба да дозна. Управо је ово још једно место на ком Јосиф глорификује своје Ја и остаје доследан својој нарцисоидности.

Начин на који овај осмогодишњак уочава и схвата ствари доказује да је Венјамин на добром путу превазилажења свога брата, који је сматран савршеним. Видевши га као свог узорног модела, Венјамин жели да има исти венац од мирте на глави као и Јосиф. Међутим, Јосиф то схвата као потенцијално угрожавање, што не показује директно, већ суптилно саветују Венјамину другачију врсту венца, од разних пољских трава. Дакле, Јосиф одбија сваку идентификацију са још неким, па макар то био и његов мали брат, што овај осмогодишњак уочава, претпостављајући да се Јосиф брине за наследство.

„Ти си, очевидно, у праву, и ја то увиђам, Јосефија, Јашупе, мој Јехосифе. Ти си неизмерно паметан и оно што ти кажеш, то ја не бих умео да кажем. Али када ти то кажеш, онда ми је све јасно и ја се приклањам твојим мислима, тако да су то онда и моје мисли, па сам ти ја тако онолико паметан колико ме 
ти начиниш паметним. Сасвим ми је јасно да се мора направити избор и да не пристаје сваком сваки украс. Видим да ћеш да останеш на томе и да ћеш ме оставити онако паметног какав сам постао слушајући тебе. Али чак и када би пошао даље и када би пред братом још отвореније говорио, ја бих те већ пратио, веруј малишану, у њега се потпуно можеш поуздати.” (Ман 1990б: 64)

„У себи је мислио [Венјамин]: Очевидно је изабраност за наследника и првородство то што има на уму. [...] У сваком случају, [Јосиф] хоће да ме увери да је мирта жртвени украс; то ме мало узнемирује и плаши.” (Ман 1990б: 66)

Иако осмогодишњак, Венјамин је у стању да добро расуђује и процени свог брата. Зна да препозна када се у Јосифу појаве струне љубоморе, страха и тајновитости. Свакако, Венјамин према Јосифу исказује свако поштовање и љубав у којој се обједињују љубав према брату и мајци. Свестан је свог судбоносног терета који прати удес смрти њихове мајке, као и очевог одабира Јосифа за наследника. Упркос свим познатим чињеницима да је Јосиф практично представљао оличење идеалног представника људске расе, са нагињањем ка божанском, закључујемо да са својих осам година млади Венјамин превазилази свог брата, јер увиђа да Јосиф препознаје његову мудрост и оштроумност, те га у извесној мери доживљава као потенцијалну претњу. Венјамин ипак сугерише брату да је свестан ко је Изабраник и да то ничим неће угрозити. Јосиф се видно срди када Венјамин поставља питања јер то значи да Венјамин сеже за већим знањима која су чак и ван Јосифових домета. Венјамин уочава потенцијалну љубомору код брата и повлачи се, увек уз речи хвале свом старијем брату, које Јосифовом самољубљу видно пријају јер их увек радо прихвата, али зна и да их узврати. Анализом односа између двојице браће, долазимо до закључка да је у Јосифу присутна извесна мера несигурности у себе, иако својом нарцисоидном појавом делује сасвим супротно. Страх од угрожавања осећа због свог мудрог млађег брата који, иако још дечак, показује извесну зрелост у промишљању и закључивању. Упркос томе, не може се порећи снажна веза између двојице браће јер, напослетку, Венјамин је једини коме ће Јосиф испричати свој важан сан ${ }^{5}$ који предсказује будућност, не само Јосифову, већ у извесној мери и читаве породице.

${ }^{5}$ Ово је први сан који се детаљно описује у роману, при чему се разликује од оних на које наилазимо што у библијској причи, то и у апокрифима. Могло би се рећи да сижејна замисао остаје иста, али је највећа разлика у детаљним описима које нам Ман предочава. У том сну, Јосиф сазнаје да ће га задесити немили догађаји, али да се због тога неће осећати лоше, већ ће, сасвим супротно, осећати извесну срећу због онога што ће уследити, а то је указивање Бога пред њима. Не само да ће му се указати Бог, већ ће он, Јосиф, бити у његовом царству, међу анђелима и Бог ће саопштити да је он његов Изабрани. Његово име ће бити „Мали Бог” (Ман 1990б: 90). Поред тога, благосиља га и краљ га на Земљи, подиже му престо сличан његовом и именује га за врховног кнеза који ће владати над свим и свима. 


\section{ПРЕОБРАЖАЈ ГОРДОГ ЈОСИФА}

Своју тетралогију Ман започиње силаском у пакао и поменом бунара, означавајући га безданом. Напомиње да су његове дубине велике онда када се ради о људском бићу и да, напослетку, уколико зађемо у дубину бунара човечије прошлости, нећемо стићи никуда јер се сваким откривањем једног дела прошлости задире у нову дубину и тако у недоглед. Зато Ман (1990а: 7) саветује да треба почети изнова и „наново све даље”, јер су те дубине недокучиве у потпуности. У Јосифовом случају, пак, важно је шта се дешава након пада у бунар, дубину и таму. Тај бунар или студенац симболично представља силазак у доњи свет који Ман помиње на самом почетку тетралогије, привремену смрт Јосифову, а затим и његово васкрсење (Мелетински 1983: 338). Рекло би се да пад, сам по себи, не може означавати нешто добро. Међутим, без пада нема ни успона, што би у Јосифовом случају значило да без пада и смрти његове нарцисоидне и гордошћу глорификоване личности нема спасења. У свом самољубљу и таштини је сагрешио, те да би био спасен мора најпре бити сахрањена његова гордост и нарцисоидност. Стога је његов сусрет са дубином студенца, како Мелетински (1983: 338) наводи, заправо и његов сусрет са „изразом сопствене подсвести у којој се човек сусреће са смрћу”. Јосифово васкрсење се потврђује боравком на дну бунара у трајању од три дана, а у наставку трећег романа Јосиф говори како је зарастању његових рана помогло уље које је намазао на себе које су му Египћани дали (Ман 1990в: 10), што представља директну алузију на васкрсење Исуса. Управо на том месту оправдава се Манова тврдња с почетка, да након пада у студенац треба почети изнова и наставити даље. Јосиф то и чини, при чему смо сведоци потпуне трансформације његове личности. Све што му се догађа у новом животу Јосиф прихвата, а самим тим показује и покорност Свевишњем. Потпуни преображај Јосиф доживљава у тренутку када својој браћи прашта учињено зло на ливади у долини Дотана и прихватања благослова који Јаков даје Јуди, јер управо ту показује да никаквој гордости ни нарцисоидности више нема трага. Можда је то и због тога што је био свестан да су ипак браћа та која су му помогла у спасењу. Напослетку, браћа су та због којих је доспео на дно бунара, те је самим тим добио прилику да започне свој процес преображаја, а он је започео оног тренутка када су га Египћани извадили из студенца. У том догађају можемо пронаћи подударност са једном од верзија апокрифа о Прекрасном Јосифу (Јовановић 2005: 291). У тој верзији апокрифа браћа су та која истичу да Јосиф не би био тамо где јесте да није било њих, његове браће која су га продала као роба и да је, поврх свега, Јосиф тај који им дугује захвалност.

Јосиф у Мановој верзији приче прелази дуг пут сазнања о добрим и лошим странама, како својим тако и туђим. То је пут сазревања и развоја на коме ће моћи да се оствари у помагању другима (Стојановић 1997: 118-119). 
Од нарцисоидног, гордог заљубљеника у себе, са очигледно искривљеном сликом доживљаја свог Ја, Јосиф сопственом трансформацијом бива спасен и тако и његов случај остаје доследан испуњењу митских образаца, оличених у потешкоћама које се морају пребродити да би се дошло до коначног добра. Имајући у виду своје праоце и њихове животне путеве, после пада у понор студенца и преображаја, Јосиф свој идентитет заправо проналази у идентитету колектива (Кордић 1975: 17), при чему смо сведоци типског које Ман помиње у понављању истих митских схема само у различитом времену. Овакав преображај сведочи о томе да тетралогија Јосифб и њеіова браћа има одлике и васпитног романа. Стојановић (1997: 175) наводи да је Јосиф прешао пут сазнања у ком је спознао да самољубље и егоизам морају бити кажњени, баш као што и Јаков кажњава себе због превелике љубави према Јосифу. У Јосифовом сазревању ка одмереном и мудром човеку, какав постаје током свог боравка у Египту, несумњиво је кључни догађај сусрет са својом подсвешћу у понору студенца. У тренутку пада постао је свестан искривљености своје свести и због тога ју је усмртио, а затим васкрсао и наставио свој пут као Божији верни слуга. За то бива и награђен. Стога можемо закључити да се, када је реч о Јосифовом развоју личности и доживљеном преображају, Ман приближава библијско-апокрифним причама о Прекрасном Јосифу. Тренутак давања опроста браћи за Јосифа заправо представља победу над сопственом таштином.

\section{ИСПУЊЕЊЕ СНА КАО ЗАКЉУЧАК И МОГУЋЕ ПОМИРЕЊЕ БИБЛИЈСКО-АПОКРИФНОГ И МАНОВОГ ЈОСИФА}

Уз све истакнуте разлике између библијске приче и апокрифних списа са Мановим приповедањем легенде о Јосифу, показало се да није изгубљена схема понављања и обнављања митских елемената које садрже и библијско-апокрифне приче и Манова тетралогија. Да би се схема понављања разјаснила, неопходно је осврнути се на шире старозаветно предање о Јосифовим праоцима и њиховим животним путевима. Извесно је да су његови праоци доживљавали слично у обрасцима, што се напослетку потврђује у понављању Јаковљевог избегавања да благослов да прворођеном Манасији. На библијска, Ман додаје и нова понављања у виду прича о Авраму и Сари, Исаку и Ребеки, Јакову и Рахили, затим у релацијама између завађене браће Каин - Авељ, Исак - Исмаел, Исав - Јаков, Јосифова старија браћа - Јосиф (Мелетински 1983: 340-341).

У чему се пак огледа поновљивост митског обрасца код Мановог Јосифа? Свакако је у питању његов развојни пут кроз који мора проћи, а у који су укључена сагрешења, спознаја сагрешења и васпостављање вредности. Нема 
сумње да је Јосиф од самог почетка врло близак Богу и својим прецима, о којима учи преко свог учитеља. Управо из учења о Богу и прецима сазнаје да човек треба бити што бољи, чак најбољи, да би се приближио Богу и задобио његову пуну наклоност. Управо ту се и налазе корени Јосифове гордости, те формира став да га сви морају волети више него што воле себе саме. Нарцисоидност која је присутна у његовом лику не прави изнимке. Глорификовању себе остаје доследан и у односу са оцем и својом браћом, чак и са млађим Венјамином, иако и сам свестан да повремено претерује у свом понашању. Његово хвалисање јаче је од љубави коју осећа према браћи, те је Јосиф сам одговоран за развој мржње коју браћа осећају према њему. Одатле можемо закључити да су негативна осећања која браћа развијају према Јосифу разумљива, при чему није оправдан чин пребијања Јосифа. Негативна осећања која су се нагомилавала у браћи имала су више етапа и била су подстакнута из више разлога: 1 . Јосифово свакодневно гордо и надобудно понашање; 2. Јосифово потказивање браће и повремено претеривање у томе; 3 . Јосифово облачење и шепурење у мајчином велу који је знак за добијање благослова; 4. Затишје лоших односа и заједнички рад у пољу; 5. Нарушавање добрих односа Јосифовим приповедањем о сну, у ком се јасно види да он господари над својом браћом; 6. Пребијање Јосифа и бацање у јаму.

У раду смо приказали значај Јосифовог пада у јаму који је проузроковао промену у његовој личности. За разлику од библијско-апокрифних прича у којима је пад у јаму била чиста неправда коју браћа чине над Јосифом и која повећава Јосифову жртву, Ман приказује бацање Јосифа у јаму као заслужену казну за његово гордо понашање и превелико самољубље које излази у први план и надилази љубав према ближњима. Бацање у јаму чини прекретницу у Јосифовом поимању себе и света око себе. Од тог тренутка поштује Божију вољу и иде у сусрет догађајима који следе, показујући особине умерене и мудре особе. Као последицу тога претрпеће још неке недаће, али ће му способност тумачења снова донети заслужено. Тумачећи сан фараону, Јосиф доспева на место које је сном већ себи предвидео. Фараон поставља Јосифа да царује над целим египатским народом што, из истих разлога као и у библијско-апокрифним причама, доводи његову браћу код њега. Тиме се Јосифов првобитни сан испуњава и старија браћа долазе пред њега, клањају му се и зависе од њега. Међутим, Јосифов преображај добија потпуни облик тек у поновном сусрету са браћом. Свестан свог ранијег гордог понашања, као и чињенице да су му браћа на известан начин помогла да спозна грешке, Јосиф прашта својој браћи зло које су починили над њим. Поред тога, мирно и искрено поштује и прихвата очеву одлуку да благослов добије Јуда, онај коме то по реду и правди припада (Стојановић 1997: 174). Томас Ман остаје доследан старозаветној причи, задржава мотив праштања и тако завршава своју исцрпну причу о Јосифу и његовој браћи. 
Истраживачки корпус компаративне анализе коју смо спровели чинили су текстови чија је тематика лик Прекрасног Јосифа. Истраживањем смо закључили да је библијска прича у свом приповедању најсажетија, али да у суштини Јосифовог лика нема никаквог одступања у односу на више верзија апокрифа који постоје. Апокрифи су детаљнији и сликовитији у самим описима, али Јосифа приказују као најузорнијег и највернијег Божијег слугу. За разлику од њих, Томас Ман Јосифов лик претвара у комплексну личност и приписује му посве другачије карактерне особине од оних које се помињу у библијско-апокрифним списима. Томас Ман преузима главни костур радње из библијско-апокрифних прича, али их проширује, убацује нове идејне замисли и остаје доследан причи о испуњењу пророчког Јосифовог сна. Оно у чему се највише разликује Манова замисао ове приче јесте остварење Јосифовог лика. Наиме, Ман приказује Јосифа у његовим младалачким данима као фигуру потпуно супротну оној из библијско-апокрифних прича. Манов Јосиф је испуњен гордошћу, који уз глорификацију своје личности навлачи на себе бес старије браће и доводи их до помисли на убилачки чин. За разлику од апокрифа и старозаветне приче где је Јосиф представљен као жртва, спреман да истрпи све недаће која га задесе, па чак и бацање у јаму и продају у робље, Манов Јосиф је морао да доживи пад у понор као казну за своје претходне поступке како би његово спасење било могуће. Снага преображаја коју доживљава падом на дно бунара, где се суочава са својом подсвешћу и васкрсава као нови Јосиф, чини да се Ман врати на пут апокрифа и библијске приче, те остане доследан испуњењу Јосифовог сна са почетка. Гордост и праштање тако постају два кључна елемента у схватању и разумевању Јосифовог лика. Лик Јосифа у Мановом роману с почетка није Прекрасни Јосиф из библијско-апокрифних сижеа, већ он то постаје на свом развојном путу.

\section{ИЗВОРИ}

Ман (1990a): Tomas Man, Josif i njegova braća I. Priče Jakovljeve, Novi Sad: Matica Srpska.

Ман (1990б): Tomas Man, Josif i njegova braća II. Mladi Josif, Novi Sad: Matica Srpska.

Ман (1990в): Tomas Man, Josif i njegova braća III. Josif u Egiptu, Novi Sad: Matica Srpska.

\section{ЛИТЕРАТУРА}

Анђелковић, Пајић (2011): Маја Анђелковић, Сања Пајић, Прича о Прекрасном Јосифу: заједничка тема српске црквене литературе и сликарства прве половине 18. века, у: Д. Бошковић, М. Анђелковић (ур.), Друшиивене кризе и савремена 


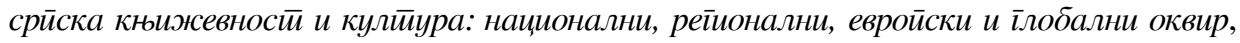
Крагујевац: Филолошко-уметнички факултет, 263-281. COBISS.SRID 514350766

Глушчевић (1970): Zoran Gluščević, Tomas Man, Jedno putovanje u središte mita, u: Mit, književnost i otuđenje, Beograd: Zodijak.

Даничић, Караџић (1992): Ђуро Даничић, Вук Стефановић Караџић, Свейо

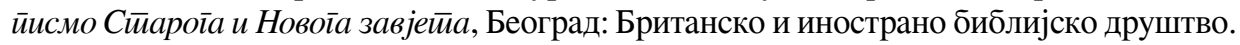

Хајмендал (1998): Hans Dieter Heimendahl, Kritik und Verklärung. Studien zur Lebensphilosophie Thomas Manns in „Betrachtungen eines Unpolitischen”, „Der Zauberberg”, „Goethe und Tolstoi” und Joseph und seine Brüder, Würzburg: Königshausen \& Neumann.

Институт за филм и слику (2012): FWU Institut für Film und Bild, Joseph und seine Brüder. Didaktische FWU-DVD, München: Das Medieninstitut der Länder. Преузето 4. 2. 2018. са сајта: http://avmat.datenbankbildungsmedien.net/vmat?nr=108829\&s=P\&labin$\mathrm{r}=108829$ \&pid=3mhu9dk7hbajprfdg0vjlcv146.

Јовановић (2005): Томислав Јовановић, Айокрифи сииарозавейни йрема срйским йрейисима, Београд: Просвета, Српска књижевна задруга.

Кордић (1975): Радоман Кордић, Психолошка вредност књижевног јунака („Легенда о Јосипу” Томаса Мана), у: Археолоїија књижевної gела, Београд: Просвета.

Клерико (2004): Mona Clerico, Welt - Ich - Sprache. Philosophische und psychoanalytische Motive in Thomas Manns Tetralogie „Joseph und seine Brüder”. Würzburg: Königshausen \& Neumann.

Мелетински (1983): Eleazar Miosevič Meletinski, Poetika mita, Beograd: Nolit.

Педерин (2008): Ivan Pederin, Thomas Mann: Judeo-krišćanski roman o starozavjetnom Josipu, Crkva u svijetu, god. 43, br. 4, Split: Katoličko bogoslovni fakultet Sveučilišta u Splitu, 508-525. Преузето 4. 2. 2018. са сајта: https://hrcak.srce.hr/file/55157.

Стојановић (1997): Драган Стојановић, Свечани час приповести. Јосиф и његова браћа, у: Параgоксални класик Томас Ман, Београд: Завод за уџбенике и наставна средства.

Тартаља (1986): Ivo Tartalja, Mitsko, tipsko i komično, Polja, god. 32, br. 324, Novi Sad: UDS, NIŠJP „Dnevnik”, 65-67. Преузето 17. 2. 2018. са cajта: http://polja.rs/ wp-content/uploads/2017/09/Polja-324-13-15.pdf.

\section{Jelena Đ. Gojić}

Universität in Kragujevac

Fakultät für Philologie und Kunst

Lehrstuhl für Germanistik

\section{DIE MOTIVE DES STOLZES UND DER VERZEIHUNG IM ROMAN VON THOMAS MANN JOSEPH UND SEINE BRÜDER MIT DEM RÜCKBLICK AUF BIBLISCHE SCHRIFTEN UND APOKRYPHEN}

Resümee: Der alte Testament enthält die Geschichte über Joseph, die nur in ein paar Kapiteln im Buch Mose dargestellt wurde, wobei es neben dieser Geschichte auch noch einige Beispiele der Schriften gibt und das sind die Apokryphen, die von der Geschichte 
über Joseph und seinem Lebensweg zeugen. Dadurch hat man die Möglichkeit, Josephs ganzes Leben und seine Entwicklung aus verschiedenen Perspektiven zu überblicken. Die vorliegende Arbeit befasst sich demzufolge mit der Beleuchtung von Josephs Figur in dem Roman Joseph und seine Brüder von Thomas Mann, wobei man mit der komparativen Analyse versucht, die mögliche Verbindung zwischen Manns Roman (Teil II, Der Junge Joseph) und Bibel-/Apokryphentexten herzustellen. Es wurde gezeigt, dass der größte Unterschied zwischen diesen Texten in dem frühen Leben von Joseph liegt, da er sich in Manns Roman so stolz benimmt und sein eigenes Ich glorifiziert.

Schlüsselwörter: Thomas Mann, Joseph und seine Brüder, Der junge Joseph, Apokryphen, Joseph, Stolz, Verzeihung. 